Eskişehir Osmangazi Üniversitesi

Sosyal Bilimler Dergisi

Nisan 2019, 20 (Özel Sayı), sayfa aralığı

DOI: 10.17494/ogusbd.

\title{
Karakter ve Değer Eğitimi Dersinin Kazanımları
}

\author{
Selçuk ŞiMŞEK, Vesile ALKAN*
}

Karakter ve Değer Eğitimi Dersinin Kazanımları

Özet

Bu araştırmada, Pedagojik Formasyon programına kayıtlı aday öğretmenlerinin program kapsamında verilen seçmeli Karakter ve Değer Eğitimi dersinden elde etmiş oldukları kazanımları ile ilgili görüşlerini elde etmek amaçlanmıştır. Bu araştırma nitel araştırma anlayışına dayalı durum çalışması yöntemine göre desenlenmiştir. 52 öğretmen adayı amaçı örneklem belirleme yöntemine göre belirlenmiştir. Araştırmada veriler, 'açık uçlu form' veri toplama aracı ile toplanmıştır. Veriler, analiz edilmiştir. Sonuçlar 5 tema altında toplanmıştır. Bu temalar; Ders boyutunda kazanımlar, Değerler boyutunda kazanımlar, Kavramlar boyutunda kazanımlar, Kişisel gelişim boyutunda kazanımlar Farkındalık boyutunda kazanımlar şeklindedir. Araştırmanın sonuçlarına göre; ders boyutunda içerik, yöntem ve değerlendirme; değerler boyutunda ise, saygı duyma, empati, değer verme; kavramlar boyutunda, değer ve karakter kavramları; kişisel gelişim boyutunda ön yargılardan kurtulma, bakış açııını değiştirme kazanımlarını elde ettiklerini söylemişlerdir.

Anahtar Kelimeler: Öğretmen Adayı, Değer, Karakter, Karakter ve Değer Eğitimi Dersi.
Learning Outcomes of The Character and Values Education Course

Abstract

In this study, the aim is to get views of prospective teachers attending Pedagogical formation program and their views into their gaining's from the selected course "Character and Values Education". The study was designed according to qualitative case study method. 52 participants were selected by purposive sampling technique. The data was collected with an openended form and descriptive analysis was used. The analysed data was grouped under 5 themes. Experiences about the course, experiences about values, experiences about concepts, experiences about personal development and experiences about awareness. According to results, prospective teachers stated that they gained information, skill, and behaviour. In such topics as content, method, evaluation, and they got experiences about values like respect, empathy and appreciation in values dimension. Prospective teachers also stated that they got knowledge about concepts related with values and character.

Key Words: Prospective Teacher, Value, Character, Character and Values Education.

\section{Giriş}

Toplumların bağlı oldukları kültürel öğeler, nesilden nesile aktarılır. Kültürlerin iyi öğelerden oluşması toplumların ilerlemesine katkı sağlarken olumsuz öğelerin varlığı toplumların zaman içinde yok olmasına neden olur. Eğitim, toplumların değer öğelerinin sürdürülebilirliğini sağlayan en önemli araçtır. Karakter ve Değer Eğitiminin eğitim ortamında sunulması, iyi ve kötü karşılaştırmalarının sağlıklı bir şekilde yapılandırıması ile toplumun ilerlemesinde sosyal bir etki sağlar. Bu ve ilişkili birçok sebepten dolayı dünya-

*Selçuk ŞiMŞEK, Dr. Öğr. Üyesi., Pamukkale üniversitesi, Eğitim Fakültesi Temel Eğitim Bölümü, selcuks@pau.edu.tr, ORCID ID orcid.org / 0000-0002-4546-7945, Vesile ALKAN, Doç. Dr., Pamukkale üniversitesi, Eğitim Fakültesi, Temel Eğitim Bölümü vesile@pau.edu.tr, ORCID ID orcid.org / 0000-0002-8630-3357

Makale Gönderim Tarihi 12/10/2018

Makale Kabul Tarihi 29/03/2019 
da uzun bir süredir eğitim kurumlarında verilmeye başlanılan 'Karakter ve Değer Eğitimi' dersi, ülkemizde de verilmeye başlamıştır.

Aslında ilk kez Antik Çağda, Platon zamanında karakter ve değer ifadelerinin vurgulandığı görülmektedir. Platon "İyi yaşam nedir?" sorusu (Randall, 1967) ile iyi yaşamın anlamını bulmaya çalışırken karakter ve değerin önemini de ortaya çıkarmıştır. Yirminci yüzyıl boyunca da Skinner, Dewey, Piaget ve Kohlberg'in insanlardaki değer gelişimine odaklandıkları görülmektedir (Berkowitz \& Puka, 2009; Dewey, 1909; Kohlberg, 1974; Piaget \& Inhelder, 2000). Kohlberg (1974), eğitim ortamında öğrencilerin birbiri ile etkileşime geçerek değer öğelerini irdelemelerinin, onlarda değer gelişimini sağlayacağına inanmıştır.

Değerler, toplumu oluşturan bireylere, nelerin önemli olduğunu, nelerin tercih edilmesi gerektiğini ve kısaca nasıl yaşanılması gerektiğini belirtir (Akbaş, 2008:10). Aynı şekilde değerler, bireyin amaçlarıyla ve bu amaçlara ulaşmada etkili olan davranış biçimleriyle (hak bilirlik, yardım severlik gibi) ilişkilerdir. (Fidan, 2009:2). Yaşaroğlu (2013:850) da değerleri, insanların iyiyi, doğruyu, güzeli ve çirkini tanımlamak için koymuş oldukları standartlar şeklinde tanımlamıştır.

Karakter, antik Yunan'da 'biçim vermek' anlamında kullanılmıştır. Bu kelime ile biçimlendirilmiş kişilik özelliklerinin bireyin kesin tavırlar içerisinde davranmasına etki edeceği vurgulanmıştır (O'Sullivian, 2004). John Dewey karakteri, alışkanlıkların yorumu şeklinde açıklamıştır (Zigler, 1998). Berkowitz (2011) ise karakteri, bireyi yetkin ahlaki temsilci gibi çalışması yani dünyada iyiyi yapması için motive edip destekleyen psikolojik özellikler grubu olarak tanımlamıştır.

Değerler ve karakter ile ilgili tanımlamalar incelendiğinde karakterin ahlaki düzenlemeye yönelik çok yönlü psikolojik özelliklere sahip olduğu görülmektedir. Bu özellikler aile ortamında gelişebildiği gibi düzenli ve istendik şekilde okul ortamında da kazandırılabilir. Karakter eğitimi, Lickona (2001) tarafından, insanın kişiliğine ait olan ahlaki bilgi, ahlaki duygu veya tutum ve ahlaki davranış konusunda bireyin eğitimi şeklinde tanımlanmıştır. Toplumun kabul edebileceği niteliklere ve kişisel özelliklere sahip bireyin iyi bir birey olduğuna inanıldığı düşünülürse bireyin ahlaki değer ve özellikler yönünden vasıflı olması gerekmektedir. Berkowitz ve Puka (2009) karakter eğitimini, bir ahlak temsilcisi gibi davranmak için yani doğru şeyleri yapmak için bireyin kendisini doğrudan motive edip desteklediği kişisel özellik öğelerinin kasıtlı teşvik edilme süreci olarak açıklamıştır. Bu durum, bireyin ahlaki anlamda kişisel gelişimi ile sosyal ve formal öğrenme ortamındaki gelişiminin önemsenmesi gerektiğini göstermektedir. 
Ülkemizde, Millî Eğitim Bakanlığı tarafından yayımlanan 8 Eylül 2010 tarih ve 2010/53 sayılı genelge ile karakter ve değer eğitimine yer verilmesi ile birlikte değerler eğitiminin önemine ilk kez değinilmiştir. Ardından günümüzde kaybolmaya yüz tutan millî, manevi, kültürel ve insani değerleri öğrencilere benimseterek gelecek nesillere aktarabilmek amacıyla "Eğitimde Değerler Eğitimi Projesi" (EDEP) hayata geçirilmiştir. MEB tarafından uygulanan projede UNESCO'nun belirlediği 12 evrensel değere de vurgu yapılmaktadır (Şentürk ve Aktaş, 2015:218). Eğitimde değer kazandırma süreci duyuşsal alanı tamamlama görevini yerine getirmektedir (Balay ve Kaya, 2014:8). Değerler eğitiminin, bireyin gelişim özellikleri, öğrenme tarzları, hazırbulunuşluk düzeyleri, ilgi, ihtiyaç ve beklentileri dikkate alınarak ve farklı öğretim yöntemleri kullanılarak yapılması değerlerin kazandırılmasında önemli rol oynamaktadır (Kılcan ve Akbaba, 2003:115).

Son yıllarda birçok ülkede görülen toplumsal yozlaşma, ahlaki değer anlayışının zedelenmesi, milli kültür ve değerlerin unutulması gibi sebepler, başta ABD olmak üzere Avrupa'daki ülkelerde ve Türkiye'de Karakter ve Değer Eğitiminin okullarda verilmesine neden olmuştur. Bu çerçevede ülkemizde okullarda nitelikli eğitimin sağlanması amacıyla Yüksek Öğretim Kurumu, 2018-2019 eğitim- öğretim yılıyla birlikte, yeni öğretim programlarını yayınlayarak Eğitim Fakültelerinde 'Karakter ve Değer Eğitimi' dersini zorunlu hale getirmiştir (YÖK, 2018). Bu ders, 2015 yılından beri Pedagojik Formasyon Eğitimi Sertifika Programında yer alan dersler içerisinde seçmeli olarak yer almıştır (YÖK, 2015). Dersin içeriğine bakıldığında, dersin amacının; ailede ve okulda, ahlak ve değerler eğitiminin ilke ve yöntemlerini kavramak ve uygulayabilmek, karakter ve değerler eğitiminin tarihsel temellerini, bireysel ve toplumsal amaçlarını, karakter ve değerler eğitimi yaklaşımlarını kavratmak olduğu görülmektedir.

Karakter ve Değer eğitimi konusunda alan yazında bazı çalışmalar (Acat ve Aslan, 2011; Akbaş, 2008; Aladağ, 2009; Balcı, 2008; Demirtaş, 2009; Dilmaç, 2007; Elbir ve BağCı, 2013; Keskinoğlu, 2008; Koç, 2007) vardır. Alan yazındaki çalışmalar incelendiğinde; bu çalışmaların çoğunun temel eğitim, ortaöğretim ve yükseköğretim düzeyinde uygulandığı görülmektedir. Ancak Pedagojik Formasyon eğitimi alan öğretmen adaylarının bu ders ile ilgili almış oldukları eğitim sonrasında elde etmiş oldukları kazanımlara yönelik olarak alan yazında ulaşılabilen bir çalışmanın bulunmadığı görülmüştür. Bu yüzden Pedagojik Formasyon eğitimi alan öğretmen adaylarının 'Karakter ve Değer Eğitimi' dersi neticesinde nasıl kazanım elde ettiklerinin bilinmesinin hem dersin amaçları hem de yapılan çalışmaların etkililiği açısından alana katkı sağlayacağı düşünülmektedir. Ayrıca bu dersin gerekliliği konusunda önemli ipuçları verecektir.

\subsection{Araştırmanın Amacı}

Bu amaçla bu araştırmada Pedagojik Formasyon program kapsamında seçimlik ders olarak sunulan 'Karakter ve Değer Eğitimi' dersini seçen öğretmen adaylarının görüşlerine 
dayalı olarak dersin öğretmen adaylarına olumlu ve olumsuz yönde kazandırdıklarını cinsiyete göre belirlemektir.

\section{Yöntem}

Karakter ve Değer Eğitimi dersi kapsamında elde edilen kazanımlar hakkında öğretmen adaylarının görüşlerini belirlemeyi amaç edinen bu araştırma, nitel araştırma anlayışına uygun olarak yapılandırılmıştır. Bu doğrultuda araştırma, katılımcıların Karakter ve Değer Eğitimi dersi ile ilgili deneyimlerini ve görüşlerini anlamak (Creswell, 2003) amacıyla durum çalışmasına göre yapılandırılmıştır. Katılımcıların derse yönelik deneyimlerinden kazandıklarının açıklanması için betimleyici durum çalışması (Lincoln ve Guba, 1985) tercih edilmiştir.

\section{1 Çalışma Grubu}

Araştırmanın amacına uygun olarak, çalışma grubu, ders ile ilgili görüşlerin ilgili gruptan alınması amacıyla amaçlı örnekleme yöntemi ile belirlenmiştir (Yıldırım ve Şimşek, 2013). Patton'a (2015) göre amaçlı örneklem, bir durumu nitelikli bir şekilde açıklamada aranan grubu belirlemek amacıyla tercih edilmelidir. Bu doğrultuda, çalışma grubu, araştırılan konuyu incelemeye katkı sağlaması amacıyla Pedagojik Formasyon eğitimi alan ve Karakter ve Değer Eğitimi dersini seçmiş olan aday öğretmenlerden oluşmuştur. Araştırmada çalışma grubunun özelliklerine göre dağılımı aşağıdaki gibidir:

Tablo 1. Cinsiyete Göre Dağılım

\begin{tabular}{ccc}
\hline \hline Cinsiyet & $F$ & $\%$ \\
Kadın & 33 & 63,5 \\
Erkek & 19 & 36,5 \\
Toplam & 52 & 100 \\
\hline
\end{tabular}

Tablo 2. Katılımcıların Bölümlere Göre Dağılımı

\begin{tabular}{lcc}
\hline \hline Bölüm adı & $F$ & $\%$ \\
\hline Türk Dili ve Edebiyatı & 5 & 9,6 \\
Ebelik & 1 & 1,9 \\
Fizik & 1 & 1,9 \\
Alman dili ve Edebiyatı & 3 & 5,7 \\
Felsefe & 3 & 5,7 \\
Matematik & 1 & 1,9 \\
Hemşirelik & 10 & 19,2 \\
\hline
\end{tabular}




\begin{tabular}{lcc}
\hline \hline Ingiliz Dili ve Edebiyatı & 2 & 3,8 \\
Kimya & 7 & 13,4 \\
Biyoloji & 1 & 1,9 \\
Sosyoloji & 3 & 5,7 \\
ilahiyat & 15 & 28,8 \\
Toplam & $\mathbf{5 2}$ & $\mathbf{1 0 0}$ \\
\hline
\end{tabular}

\subsection{Veri Toplama Aracı}

Araştırmada veriler, geliştirilen 'açık uçlu form' yardımı ile toplanmıştır. Amaca uygun olarak geliştirilen bu form, yapılandırılmış sorulardan oluşmuştur. Sorulan sorular, öğretmen adaylarının kapsamlı açıklama yapmalarını sağlayacak yapıdadır. Bunun için yapılandırılan form ön uygulama yapılarak denenmiş ve son hali verilmiştir. Ön uygulama sayesinde, veri toplama aracının inandırıcılık ve teyit edilebilirlik de desteklenmiştir.

\subsection{Verilerin Analizi}

Araştırmadan elde edilen veriler, betimsel analiz yöntem kurallarına göre analiz edilmiştir. Analiz sırasında öğretmen adaylarının cevapladıkları formlar numaralandırılmış ve bu numaralar ile katılımcılar isimlendirilmiştir. Bu numaralar, bulguların sunumunda öğretmen adaylarını temsil etmiştir. Pedagojik Formasyon programında Karakter ve Değer Eğitimi dersi, iki saat teorik olarak yer almaktadır. Ancak dersin öğretim elemanı tarafından ders teorik ve uygulamalı şeklinde yürütülmüştür.

\section{Bulgular}

Analiz sonucunda elde edilen bulgular, beş tema altında toplanmıştır. Bunlar;

1. Ders boyutunda kazanımlar

2. Değerler boyutunda kazanımlar

3. Kavramlar boyutunda kazanımlar

4. Kişisel gelişim boyutunda kazanımlar

5. Farkındalık boyutunda kazanımlar şeklindedir. 
Selçuk ŞiMŞEK | Vesile ALKAN

Elde edilen temaların cinsiyete göre dağılımları Şekil 3'te gösterilmiştir.

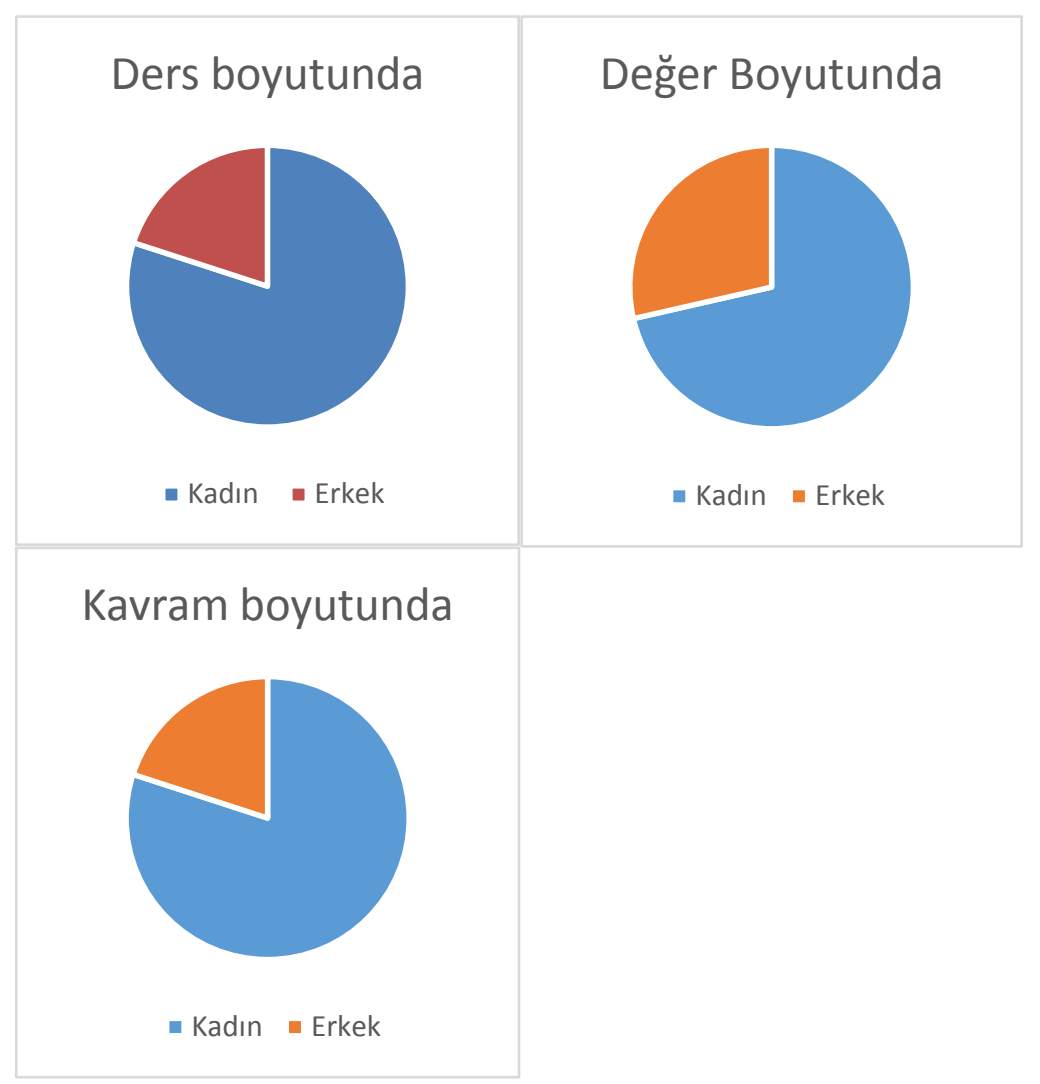




\section{Kişisel Gelişim boyutunda}

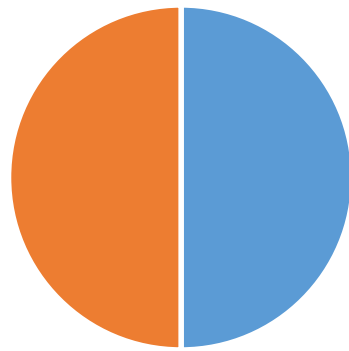

$$
\text { - Kadın Erkek }
$$

\section{Farkındalık boyutunda}

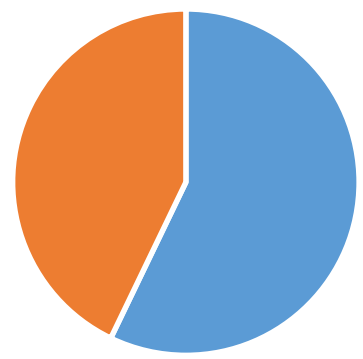

- Kadın Erkek

Şekil 3. Cinsiyete Göre Temaların Dağııımı

Cinsiyet açısından bakıldığında dersi seçen öğretmen adayı kadın olanların sayısı 33 iken erkek öğretmen adayı sayısı ise 19 dur. Toplamda 52 öğretmen adayı dersi seçmiştir. Buna göre bakıldığında her temaya göre dağııııın kadın öğretmen adayları lehine olduğu görülmektedir. Sadece kişisel gelişim boyutunda eşit olarak dağılımın gerçekleştiği görülmektedir. Bunun dışında bölümler açııından bakıldığında her temaya göre eşit düzeyde dağılım gösterdiği görülmektedir.

\subsection{Ders Boyutunda Kazanımlar}

Ders boyutundaki kazanımları kendi içerisinde üç temel başlık altında toplanmıştır. Bunlar; içerik, öğrenme-öğretme süreci ve değerlendirme boyutlarıdır. İlk olarak içerik boyutuna bakıldığında, öğretmen adayları tarihsel süreç anlamında kazanımlar elde ettiklerini belirtmişlerdir. 51 nolu öğretmen adayı "Olumlu tarafı karakter ve değerler eğitiminin tarihçesini ve süreçlerini öğrendim." diyerek tarihsel süreciyle ilişkili bilgi edinimi sağladığını söylemiştir. Yine içerik olarak derslere yansıtma konusunda kazanım elde eden öğretmen adayı bulunmaktadır. 41 nolu öğretmen adayı "Aslında kavram olarak bildiğimiz, uygulamada eksik kaldığımız, iletişimde önemi büyük olan değerlerimizi derste tartışma şansı buldum. Öğretmen olarak çalıştı̆̆ım kurumda derslerime yansıtma olanağı buldum." diyerek görüşünü belirtmiştir. 


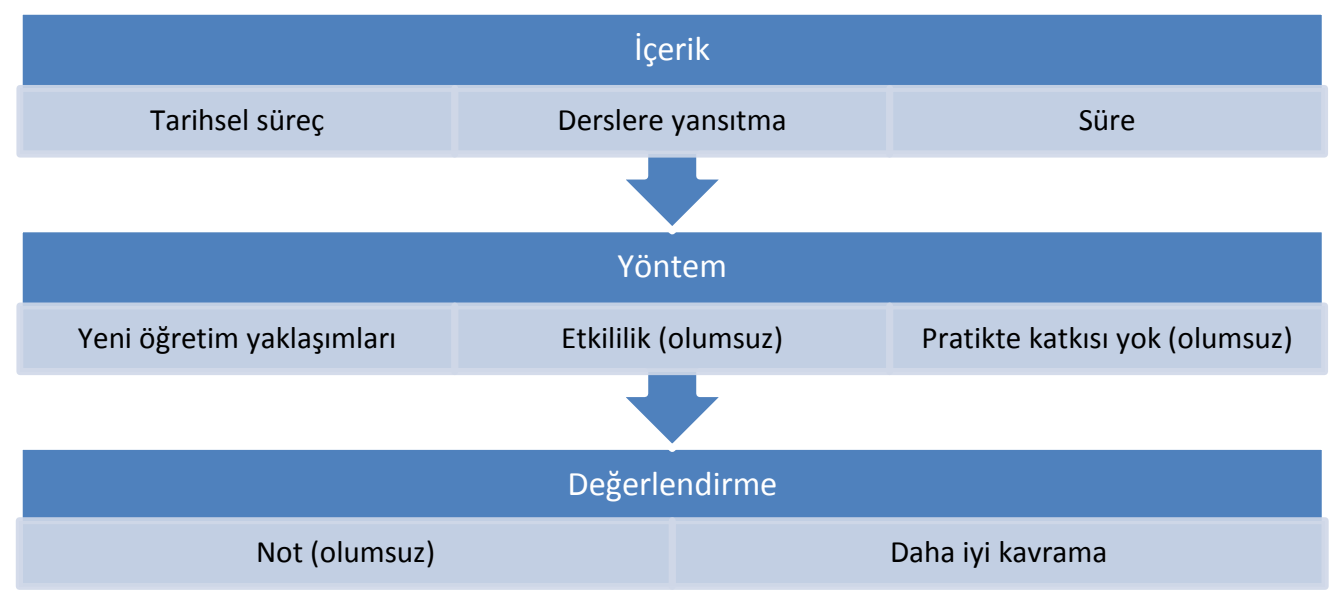

Şekil 4. Ders Boyutunda Kazanımlar

Dersin kazanımları boyutu içerisinde yöntemlerle ilgili kazanımları olduğunu belirten öğretmenler de olmuştur. Bunlardan 33 nolu öğretmen adayı "Model alma yoluyla öğrenmenin kişiye etkisinin ne kadar fazla olduğunu daha iyi anladım." şeklindeki ifadesi ile; 43 nolu öğretmen adayı da "Değerler eğitimini bu dersle birlikte aldıktan sonra değerlerin kendi içinde ayrımları ve basamakları olduğunu öğrendim. (Telkin yaklaşımı, Değer açıklama vb...)" diyerek değerler eğitimi içerisinde kullanılan yöntem ve yaklaşımlardan bahsetmişlerdir. Olumsuz olarak gören öğretmen adayları da vardır. 38 nolu öğretmen adayı "Ben bu dersten çok şey bekliyordum. Fakat beklentimi tam olarak karşıladığını düşünmüyorum. Bölümümüzü çok yakından ilgilendiren bir dersti. Değerler eğitiminin nasıl olması gerektiğini pratik olarak da görmeyi umuyordum. Teorikte bir şeyler kazandırdı. Ama yaşantı anlamında öğretim olarak faydalanamadım." diyerek görüşlerini belirtmiştir.

Değerlendirme boyutu içerisinde olabilecek olan not kazanımı hakkında öğretmen adayının olumsuz bir bakışı olduğu görülmektedir. Örneğin 09 nolu öğretmen adayı dersten elde ettiği kazanımı "Ben bu derse katıldım ama sınavdan aldığım not ortada. 30 aldım ve yeterince açık, doğru yazdığımı düşünüyorum." diyerek görüş belirtmiştir. 36 nolu öğretmen adayı ise "Olayları değerlendirme, farklı noktalardan bakabilme, fikir geliştirme vb... gibi yönlerden gelişim sağladım diyebilirim. Derse tam adaptasyon sağlasaydım daha fazla verimli olurdum." görüşüyle değerlendirme yönünün geliştiğini belirtmiştir.

Dersin içeriği konusunda 37 nolu öğretmen adayı "Bu ders bizde olması gerekenleri göz önünde bulundurmamı gerektiğini gösterdi. Derse içeriğe bakınca gerçek, olması gereken, Peygamber efendimizin anlattığı, insanlara aktarmaya çalıştığı insanlık davranışlarıyla örtüşür gibiydi. Aslında dersin içeriği güzeldi ama bunların kişilik oturmadan daha 
erken dönemlerde ders olarak verilmesi daha uygun olurdu diye düşünüyorum." diyerek ders içeriği konusundaki görüş ve değerlendirmesini yapmıştır.

\subsection{Değerler Boyutunda Kazanımlar}

Değerler boyutundaki kazanımlara bakıldığında; öğretmen adayları bazı değerlerin kendileri açısından önemli olduğunu vurgulamışlardır. Bunların başında empatinin geldiği görülmektedir. Çünkü toplumsal olarak insanların birbiriyle sağlıklı iletişim kurmalarında empatinin önemli olduğu ve bunun için başkasının yerine kendini koyarak tutum ve davranış içerisinde bulunmak gerektiği belirtilmektedir. 3 nolu öğretmen adayı "En başta "empati" duygusunu harekete geçirdiğini düşünüyorum. Sınıfta verilen örnekler de kişi ve olayların öznesi olduğumu düşündüm, benim yaşadığımı ve benim adlandırdığımı düşündüğüm çok an oldu." diyerek empati kurarak yaşama bakmanın gerekliliğini vurgulamıştır. 15 nolu öğretmen adayı "Dersin bize kazandırdıkları insanlara neye göre değer vereceğimizi, hangi kriterlere göre değerlendireceğimizi kazandırdı. Unuttuğumuz veya unutmaya yüz tutulan değerleri hatırlattı." diyerek değer vermenin önemini belirtmektedir.

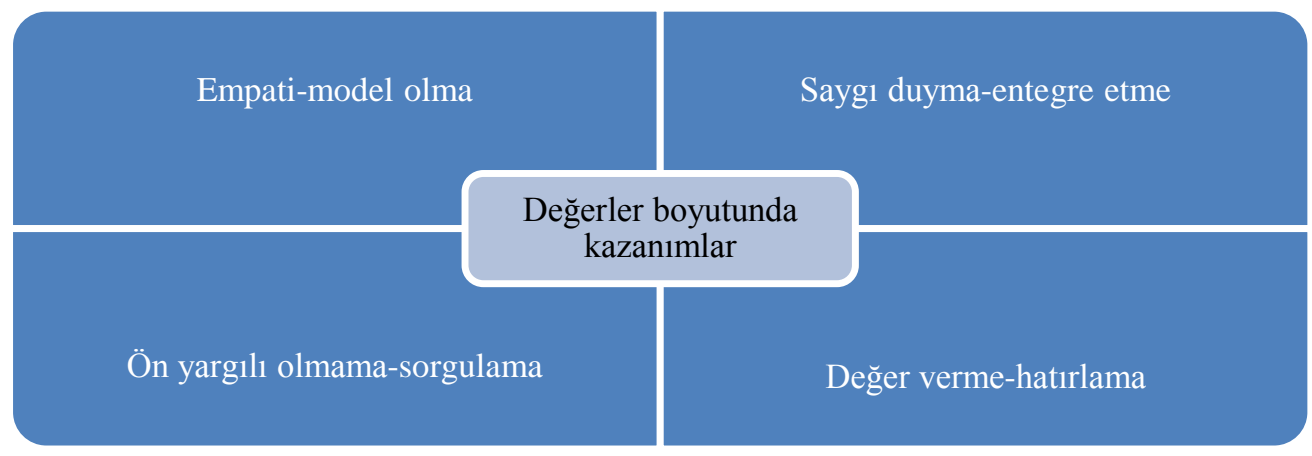

Şekil 5. Değerler Boyutunda Kazanımlar

İnsan yaşamındaki önemli bakış açılarından birisi de yargılarımızdır. En önemlisi önyargılarımızdır. Değerler eğitimi sürecinde bundan kurtulmak gerektiği konusunda öğretmen adaylarının kazanımları dikkat çekicidir. 28 nolu öğretmen adayı "insanın değer kavramını değerlendirirken, yanılgıya düşmesi tam ifade edebilmesinin çok zor olduğunu, olumsuz yönlerde bazen olumlu değer olabileceğini dolayısıyla bir olay gerçekleştiğinde hemen önyargılı olmamalı, peşin hükümlerden kaçınmak gerektiğini öğrendim." diyerek önyargılardan kurtulmanın gerekliliğini belirtmiştir. 


\subsection{Kavramlar Boyutunda Kazanımlar}

Bu boyutta dikkati çeken en önemli kavram değer ve karakter kavramlarıdır. Öğretmen adayları, dersin doğasına uygun olarak bu iki kavramın önemini bilerek bunu kazanım olarak gördüklerini belirtmişlerdir. Bu dersin içinde önemli kavramlar bulunmaktadır. Bunun yanında dersin içeriğinde yer alan yöntemler, değerlendirme, karar verme, erken yaş, yaş grupları gibi önemli kavramları bilmek istemeleri dikkat çekici kazanımlar olarak görülmektedir. 8 nolu öğretmen adayı "Değer diye bir kavram olduğunu öğrendim. Ve bu kavramın hayatımızda ne kadar büyük bir yeri olduğunu... Insanların değer kavramlarının farklı olduğunu ve buna saygı göstermemiz gerektiğini öğrendim." diyerek görüşünü belirtmiştir. 40 nolu öğretmen adayı ise "Değerler eğitimi dersi yeni şeylerin farkına vardık. Örneğin "değer ve karakter" sözcüklerinin anlamını öğrendik." diyerek görüşünü belirtmiştir. Kavramlar içerisinde dikkat çeken bir kavram da erken yaş kavramıdır. Çünkü değerlerle ilgili eğitime erken yaşta başlamanın gerektiği hep belirtilmektedir.

\begin{tabular}{|c|c|c|}
\hline \multicolumn{3}{|c|}{ Değer } \\
\hline Bakış açısı & Erken yaş & Farklılıklar \\
\hline \multicolumn{3}{|c|}{ Karakter } \\
\hline Karar verme & Mukayese & Yaş grupları \\
\hline \multicolumn{3}{|c|}{ Önemi } \\
\hline Sorgulama & Değerlendirme & Yöntemler \\
\hline
\end{tabular}

Şekil 6. Kavramlar Boyutunda Kazanımlar

\subsection{Kişisel Gelişim Boyutunda Kazanımlar}

Kişisel gelişim boyutu aslında bireyin gelişim sürecinde önemli bir yer kaplamaktadır. Burada özellikle öğretmen adaylarının değer ve karakter eğitimi sürecinin insan temelli bir anlayışla gerçekleştirilmesi noktasında hem fikir olduklarını söyleyebiliriz. Bir de her bireyin farklılıklarının olabileceği ve buna göre gelişiminin olabileceği noktasında kazanımlar elde etmiş olmaları da önemli olarak görülebilir. Bir diğer nokta da her bireyin anne-baba rollerinin olabileceği gerçeğidir. Burada bu özelliğe de dikkat çekilmiş olması önemli olarak görülebilir. 22 nolu öğretmen adayı "Bu dersi aldıktan sonra günlük diyaloglarda kullandığımız sözcükler ve bu sözcüklerin anlamlarını daha dikkatli bir şekilde kullanmaya başladım. Ayrıca insanları bir arada tutan sosyal yaşamdaki ölçütlerini sorgulamaya başladım. Birine yol göstermenin ya da yardım etmenin doğuracağı sıkıntıları ve artıları da göz önünde bulundurmaya başladım." diyerek kişisel gelişimi açısından yeni bir bakış açısı 
kazandığını belirtmektedir. Bu da kazanımlar açısından önemli sayılabilir. Ebeveynlik açısından bakıldığında 48 nolu öğretmen adayı "Değerler ve karakter eğitimi dersinin konularını ben daha çok annelik vasfımı geliştirmek için ve çocuklarıma daha iyi ve doğru değerleri kazandırabilmem açısından olumlu katkılarının olduğunu düşünüyorum. Dersin içeriğinin kişiye olumsuz bir katkı sağlayabileceğini düşünmüyorum." diyerek görüş belirtmiştir. Annelik yönünün gelişiminde dersin önemli bir rol üstlendiğini söylemesi dikkat çekici bir durum olarak karşımızda durmaktadır.

\section{Kişisel Gelişim Boyutunda Kazanımlar}

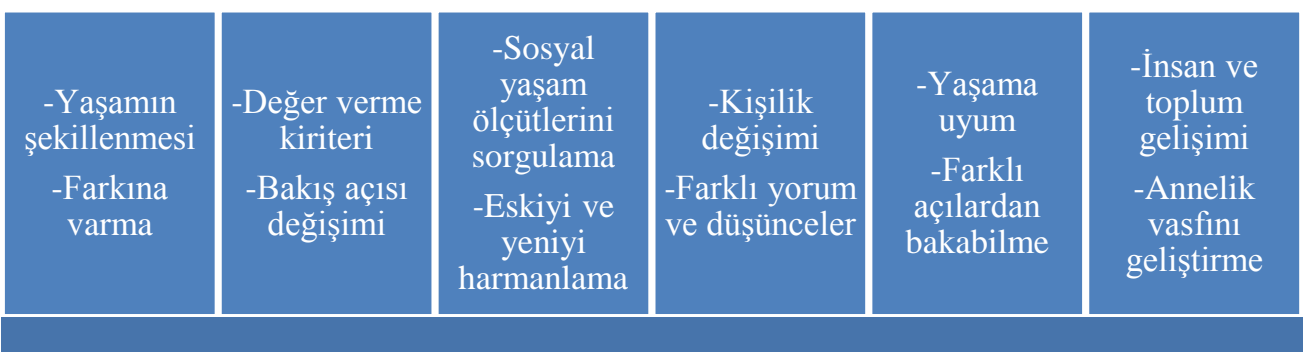

Şekil 7. Kişisel Gelişim Boyutunda Kazanımlar

\subsection{Farkındalık Boyutunda Kazanımlar}

Araştırmaya katılan öğretmen adaylarının kazanımlar noktasında belirtmiş oldukları görüşleri içerisinde bir boyutu da farkındalık boyutu oluşturmaktadır. Bu boyutta öğretmen adaylarının dersin verilip verilmediği hususunda fikri olmadığı ancak dersle birlikte bu bilgiyi kazandığı görülmektedir. 5 nolu öğretmen adayı "Değer eğitiminin okul dönemindeki çocuklara verildiğini bilmiyordum. 5 yaşındaki çocuğumun okulda değerler köşesi olduğunu dersi aldığım dönemde daha dikkatli inceleme fırsatım oldu. Her okulda etkili şekilde verildiğini düşünmüyorum." diyerek ders sırasında dersin okullarda verildiğinin farkına vardığını belirtmiştir. 


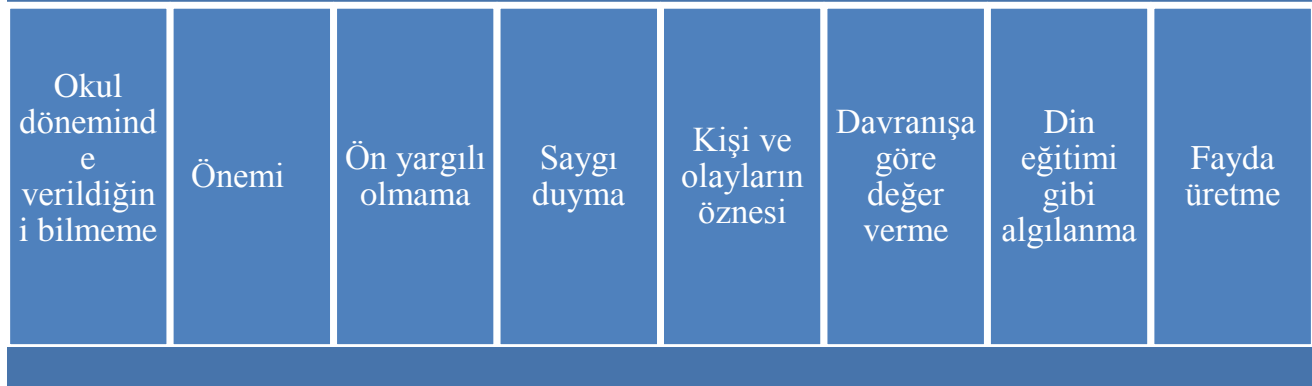

Şekil 8. Farkındalık Boyutunda Kazanımlar

Dersin önemi hususuna bakıldığında öğretmen adaylarının farkındalığının geliştiğini görmekteyiz. Ayrıca dersin gerekliliği noktasında da aynı düşünceyi taşıdıkları söylenebilir. 31 nolu öğretme adayı "Öncelikle değer kavramının ne olduğunu tam manasıyla öğrendiğime inanıyorum. Bu öğrendiğim değerleri öğrencilere verebilmemin önemini kavradım. Yani öğretmen olduğumda ya da hayatımın her alanında bildiğim, inandığım toplumda kabul görmüş değerlerimizin devamlılığını sağlamanın önemini kavradım." diyerek görüşünü belirtmiştir.

\section{Sonuç ve Tartışma}

Bu araştırmanın amacı Pamukkale Üniversitesi Eğitim Fakültesi Pedagojik Formasyon eğitimi alan ve Karakter ve Değer Eğitimi dersini seçen öğretmen adaylarının dersten kazanımları ile ilgili görüşlerini ortaya çıkarmaktır. Bu amaca uygun olarak bu araştırma, nitel anlayış çerçevesinde durum çalışması yöntemine göre yapılandırılmıştır. Amaçlı örneklem belirleme tekniklerine göre belirlenen çalışma grubundan, veriler, geliştirilen 'açık uçlu form' yardımı ile toplanmıştır.

Araştırmadan elde edilen verilere göre, katılımcıların görüşlerinin aşağıda belirtilen temalar altında toplandığı görülmüştür. Temalar şu şekildedir:

1. Ders boyutunda kazanımlar: Öğretmen adayları bu boyutta içerik, öğrenme öğretme süreci ve değerlendirme alt boyutlarında kazanım elde ettiklerinden bahsetmişlerdir. 
2. Değerler boyutunda kazanımlar: Öğretmen adayları bu boyutta empati değerini kazandıklarına vurgu yapmakla birlikte, önyargılardan kurtulma, değer verme ve saygı duyma kazanımlarını dile getirmişlerdir.

3. Kavramlar boyutunda kazanımlar: Öğretmen adayları öncelikle değer ve karakter kavramını öğrendiklerini dile getirmekle birlikte; erken yaş, yöntemler, değerlendirme ve karar verme gibi kavramları öğrendiklerini söylemişlerdir.

4. Kişisel gelişim boyutunda kazanımlar: Öğretmen adayları bu boyutta yeni bir bakış açısı kazanma, her bireyin farklı olduğunu kabullenme kazanımlarına vurgu yaptıkları görülmektedir.

5. Farkındalık boyutunda kazanımlar: Öğretmen adayları bu boyutta değerler eğitiminin okul döneminde verildiği ve değerlerin devamlılığının sağlanmasının önemini farkına vardıklarını belirtmişlerdir.

Elde edilen bulgulardan kavramsal boyuttaki kazanımda belirtilen "erken yaş" kavramındaki gibi Değer kazanma sürecinin (Silah, 2000) ve (Doğanay, 2009) tarafından belirtilen erken yaş ve küçük yaş ifadeleriyle benzerlik taşıdıkları görülmektedir. Neslitürk ve Deniz (2014) tarafından gerçekleştirilen araştırma neticesinde "empati" vb. becerilerin kazanımının arttığı sonucuna varılmıştır. Buna göre araştırmanın "değer boyutundaki kazanımlar" dan elde edilen "empati" kavramıyla benzerlik taşıdığı söylenebilir. Kılcan (2016) tarafından gerçekleştirilen araştırma bulgularında da değer öğretiminin farklı yöntemlerle gerçekleştirilmesinin uygun olacağı belirtilmiştir. Bu araştırmanın kazanımlarından "ders boyutunda" da yeni öğretim yaklaşımlarından bahsedilmiş olmasıyla benzerlikler taşıdığı söylenebilir. Aladağ ve Karaman (2018) tarafından gerçekleştirilen araştırmada kullanılan filmlerin değer eğitiminde katkı sağladığı belirtilmektedir. Bunun gibi bu araştırmada belirtilen farklı yöntemler ve yaklaşımlar kazanımıyla benzerlik taşıdığı söylenebilir. Aladağ, 2009; Balcı, 2008; Demirtaş, 2009; Dilmaç, 2007; Keskinoğlu, 2008; Koç, 2007 tarafından gerçekleştirilen araştırmalarda uygulamalı olarak gerçekleştirilen değerler eğitiminin öğrencilere olumlu katkılar sağladığı belirtilmiştir. Bu araştırmadaki farklı yaklaşımlar kazanımıyla benzerlikler taşıdığı söylenebilir.

Bu araştırma, Pedagojik Formasyon programına devam eden aday öğretmenler ile yürütülmüştür. Benzer bir çalışma Eğitim Fakültesinde eğitim gören öğrenciler ve okullarda görev yapan öğretmenler ile de yürütülerek alana katkı sağlanabilir. Ayrıca görüşme teknikleri ile de daha detaylı bilgiye ulaşılması mümkündür.

\section{Kaynaklar}

Acat, M. B. ve Aslan, M. (2011). Okulların karakter eğitimi yetkinliği ölçeği (OKEYÖ). Değerler Eğitimi Dergisi, 9 (21), 7-27.

Akbaş, O. (2008). Değer eğitimi akımlarına genel bir bakış, Değerler Eğitimi Dergisi $6(16), 9-27$. 
Selçuk şiMŞEK | Vesile ALKAN

Aladağ, S. (2009). Illköğretim sosyal bilgiler öğretiminde değer eğitimi yaklaşımlarının öğrencilerin sorumluluk değerini kazanma düzeyine etkisi (Yayımlanmamış doktora tezi). Gazi Üniversitesi, Ankara.

Aladağ, E. ve Karaman, B. (2018). Değer eğitiminde kısa filmlerden yararlanma: örnek bir uygulama, Adnan Menderes Üniversitesi, Sosyal Bilimler Enstitüsü Dergisi, 5 (1), 360377.

Balcı, N. (2008). Illköğretim 6. sınıf sosyal bilgiler dersinde değer eğitiminin etkililiği (Yayınlanmamış yüksek lisans tezi). Marmara Üniversitesi, İstanbul.

Balay, R. ve Kaya, A. (2014). Eğitim Fakültesinde okuyan öğretmen adaylarının ahlaki değer yönelimleri, Değerler Eğitimi Dergisi, 12 (28), 7-45.

Berkowitz, M. W., \& Puka, B. (2009). Dissent and character education. In M. Gordon (Ed.), Reclaiming dissent: Civic education for the 21st century (ss. 107-130). Amsterdam: Sense Publishers.

Berkowitz, M. W. (2011). What works in values education. International Journal of Educational Research, 50 (3), 153-158. doi:http://dx.doi.org.libproxy.temple.edu /10.1016/j.ijer.2011.07.003

Creswell, J. W. (2003). Research design qualitative and quantative approaches. (2nd Ed.) Thousand Oaks, CA. Sage Publication

Demirtaş, S. (2009). Çocuk yuvasında kalan korunmaya muhtaç çocukların değer eğitiminde yaratıcı dramanın etkililiği (Yayımlanmamış doktora tezi). Hacettepe Üniversitesi, Ankara.

Dewey, J. (1909). Moral principles in education. Boston, MA: Houghton Mifflin.

Dilmaç, B. (2007). Bir grup fen lisesi öğrencisine verilen insani değerler eğitiminin insani değerler ölçeği ile sınanması (Yayımlanmamış doktora tezi). Selçuk Üniversitesi, Konya.

Dilmaç, B., Bozgeyikli, H., Çıkılı, Y. (2008). Öğretmen adaylarının değer algılarının farklı değişkenler açısından incelenmesi, Değerler Eğitimi Dergisi, 6 (16), 69-91,

Doğanay, A. (2009). Değerler eğitimi. C. Öztürk (Ed.). Hayat bilgisi ve sosyal bilgiler öğretimi yapılandırmacı bir yaklaşım (içinde). Ankara: Pegem A Yayıncılık.

Elbir, B. ve Bağcı, C. (2013). Değerler eğitimi üzerine yapılmış lisansüstü düzeyindeki çaIışmaların değerlendirilmesi. Turkish Studies, 8 (1), 1321-1333.

Fidan, K. N. (2009). Öğretmen adaylarının değer öğretimine ilişkin görüşleri. Kuramsal Eğitimbilim, 2 (2), 1-18. 
Keskinoğlu, M. Ş. (2008). Ilköğretim beşinci sınıf öğrencilerine uygulanan mesnevi temelli değerler eğitimi programının ahlaki olgunluğa ve saldırganlık eğilimine etkisi (Yayınlanmamış yüksek lisans tezi). Yeditepe Üniversitesi, İstanbul.

Kılcan, B. (2016). Öğretmen adaylarının, değerlerin kazandırılmasına yönelik görüşleri ile değerler eğitimine ilişkin algılarında değerler eğitimi dersinin rolü. Uluslararası Sosyal Araştırmalar Dergisi, 45, (9), 605-618.

Kılcan, B. ve Akbaba, B. (2003). Sosyal Bilgiler Öğretim programında yer alan kültürel mirasa duyarlılık değerine ilişkin öğrenci algılarının incelenmesi, ZFWT, 5(3), 113137.

Koç, K. (2007). Ilköğretim 7. sınıflarda okutulan vatandaşlık ve insan hakları eğitimi dersinde öğrenciye kazandırılması amaçlanan evrensel değerlere ilişkin tutumlar üzerinde öğretim sürecinin etkisi (Yayımlanmamış yüksek lisans tezi). Fırat Üniversitesi, Elazığ.

Kohlberg, L. (1974). Education, moral development and faith. Journal of Moral Education, 4 (1).

Lickona, T. (2001). What is good character? Reclaiming children and youth, 9(4), 239-251. http://search.proquest.com/docview/214194284?accountid=14270sitesinden alınmıştır.

Lincoln, V. ve Guba, E. (1985). Naturalistic inquiry. London: Sage Publications

Neslitürk, N, Deniz, M. E. (2014). Anne değerler eğitimi programının 5 - 6 yaş çocuklarının sosyal beceri düzeylerine etkisi, Pegem Eğitim ve Öğretim Dergisi, 4 (4), 2014, 103116.

O'Sullivan, S. (2004). Books to live by: Using children's literature for character education. Reading Teacher, 57(7), 640-645.

Patton, M. Q. (2015). Qualitative research \& evaluation methods: Integrating theory and practice (4th ed.). Thousand Oaks, CA:Sage.

Piaget, J. \& Inhelder, B. (2000). The psychology of the child. New York, NY: Basic Books.

Randall, J. H. (1967). Plato's treatment of the theme of the good life and his criticism of the spartan ideal. Journal of the History of Ideas. 28(3), 307-324. DOI: $10.2307 / 2708621$

Silah, S. (2000). Sosyal psikoloji. Ankara: Gazi Kitabevi. 
Skinner, R. (2004). Character education. Education Week on the Web. http://www.edweek.org/context/topics/issuespage.cfm?id=112 sitesinden alınmıştır.

Şentürk, L. ve Aktaş, E. (2015). Türkiye'de ve Romanya'da okutulan ana dili türkçe ders kitaplarının değer iletimi açısından karşılaştırılması, Değerler Eğitimi Dergisi, 13(29), 215-243

Yaşaroğlu, C. (2013). Hayat Bilgisi dersi kazanımlarının değerler eğitimi açısından incelenmesi. Turkish Studies, 8 (7), 849-858.

Yıldırım A. ve Şimşek H. (2013). Sosyal bilimlerde nitel araştırma yöntemleri. Ankara: Seçkin Yayıncılık Sanayi Ticaret A. Ş. 